\title{
New record of the lace bug species Acalypta marginata (Wolff) (Hemiptera: Heteroptera: Tingidae) from Japan
}

\author{
Jun Souma $\ddagger$ § \\ ‡ Entomological Laboratory, Graduate School of Bioresource and Bioenvironmental Sciences, Kyushu University, Fukuoka, \\ Japan \\ $\S$ Research Fellowship for Young Scientists (DC1), Japan Society for the Promotion of Science, Tokyo, Japan
}

Corresponding author: Jun Souma (kodokusignal@gmail.com)

Academic editor: Nikolay Simov

Received: 07 Jan 2021 | Accepted: 02 Feb 2021 | Published: 25 Feb 2021

Citation: Souma J (2021) New record of the lace bug species Acalypta marginata (Wolff) (Hemiptera:

Heteroptera: Tingidae) from Japan. Biodiversity Data Journal 9: e62868. https://doi.org/10.3897/BDJ.9.e62868

\section{Abstract}

\section{Background}

The lace bug species Acalypta marginata (Wolff, 1804) has, to date, been widely known to occur in the Palaearctic Region, but has not been recorded from Japan.

\section{New information}

Acalypta marginata is recorded from Japan for the first time. Its habitat in Japan is the grassland of Hokkaido. A key to the species of Acalypta occurring in Japan is provided.

\section{Keywords}

Heteroptera, Tingidae, Acalypta marginata, lace bug, new record, key to species, Japan, Hokkaido 


\section{Introduction}

The lace bug species Acalypta marginata (Wolff, 1804) (Hemiptera: Heteroptera: Tingidae) is widely distributed in the Palaearctic Region (Péricart and Golub 1996, Aukema et al. 2013). In eastern Asia, this lace bug has been known to occur in Korea and Mongolia to date (Golub 1982, Cho et al. 2020).

In Japan, seven species of the genus Acalypta Westwood, 1840, namely: A. cooleyi Drake, 1917, A. gracilis (Fieber, 1844), A. hirashimai Takeya, 1962, A. miyamotoi Takeya, 1962, A. pallidicoronata Souma, 2019, A. sauteri Drake, 1942 and A. tsurugisana Tomokuni, 1972 have been recorded to date (Yamada and Ishikawa 2016, Souma 2019, Souma 2020).

Recently, I sorted a collection of Heteroptera from Hokkaido, Japan and found an undetermined species of Acalypta. After careful morphological examination, I concluded that the undetermined species represents $A$. marginata. Here, I report $A$. marginata from Japan for the first time. Additionally, I provide a key to Acalypta species occurring in Japan.

\section{Materials and methods}

Dried specimens were used. Morphological characteristics were observed under a stereoscopic microscope (SZ60, Olympus, Tokyo, Japan). Specimens were photographed using a digital microscope (VHX-1100, Keyence, Osaka, Japan). Distribution records of species were mapped using SimpleMappr (Shorthouse 2010). Geographical coordinates were obtained from Google Maps. The terminology used in this study generally follows that of Drake and Ruhoff (1965). All the specimens used in this study were deposited at the Laboratory of Entomology, Faculty of Agriculture, Tokyo University of Agriculture, Kanagawa, Japan (TUA).

\section{Taxon treatment}

\section{Acalypta marginata}

\section{Nomenclature}

Acanthia marginata: Wolff 1804: 132, new species, description and figures.

Acalypta marginata: Horváth 1906: 26, new combination, description; Putshkov 1974Horváth 1906: 169, monograph, description and figures; Golub 1982: 201, distribution and biology; Péricart 1983: 111, monograph, description and figures; Golub 1988: 140, key to species and figures; Péricart and Golub 1996: 8, catalogue; Rédei et al. 2004: 75, biology; Rintala and Rinne 2011: 74, monograph, description and figures; Aukema et al. 2013: 58, catalogue; Cho et al. 2020: 738, distribution and biology. 


\section{Materials}

a. islandGroup: Japanese archipelago; island: Hokkaido; country: Japan; stateProvince: Hokkaido; municipality: Abashiri; locality: Oketo-chô, Nakayama-fûketsu; decimalLatitude: 43.58597226; decimalLongitude: 143.4748237; geodeticDatum: WGS84; samplingProtocol: none specified; eventDate: 1994-07-08-20; individualCount: 3; sex: male; lifeStage: adult; recordedBy: Shigehisa Hori; identifiedBy: Jun Souma; dateldentified: 2019; institutionCode: TUA; basisOfRecord: PreservedSpecimen

b. islandGroup: Japanese archipelago; island: Hokkaido; country: Japan; stateProvince: Hokkaido; municipality: Shirataki-mura; locality: Mt. Hirayama; decimalLatitude: 43.77086032; decimalLongitude: 143.02416775; geodeticDatum: WGS84; samplingProtocol: pitfall trap near Japanese butterbur; eventDate: 1993-07-20; individualCount: 2; sex: male; lifeStage: adult; recordedBy: Shigehisa Hori; identifiedBy: Jun Souma; dateldentified: 2019; institutionCode: TUA; basisOfRecord: PreservedSpecimen

\section{Diagnosis}

Acalypta marginata can be differentiated from other species of Acalypta by a combination of the following characteristics: both macropterous and brachypterous morphs known; body fuscous, elongate in brachypterous morph (Fig. 1a, b) and oblong in macropterous morph; antenniferous tubercles obtuse, slightly curved inwards; basal part of antennal segment III not thickened; rostrum reaching posterior margin of metasternum (Fig. 1c); pronotum tricarinate, 0.8 times as long as maximum width across paranota; hood concealing basal eighth of vertex; pronotal carinae laminate; calli coarsely punctate; paranotum with 2 rows of areolae at widest part; anterolateral angle of paranotum rounded, not protruding anteriad; posterolateral angle of paranotum not protruding posteriad; posterior process 2.2 times as wide as its length; posterior margin of hemelytron in brachypterous morph weakly sinuate; gap between both hemelytra in brachypterous morph distinctly narrower than discoidal area at widest part of each; costal area with a single row of areolae throughout its length; subcostal area with 3-5 rows of areolae at widest part; discoidal area with 3-5 rows at widest part, expanded beyond apical fourth of hemelytron in brachypterous morph, as wide as subcostal area at widest parts of each; and basal third of discoidal-sutural boundary vein carinate.

\section{Distribution}

Japan (Hokkaido) (Fig. 2), Armenia(?), Austria, Azerbaijan, Belgium, Bosnia Herzegovina, Bulgaria, Byelorussia, Croatia, Czech Republic, Finland, France, Germany, Hungary, Italy, Latvia, Luxembourg, Moldavia, Mongolia, Netherlands, Norway, Poland, Portugal, Romania, Russia, Serbia, Slovakia, Slovenia, Spain, Sweden, Switzerland, Turkey, Ukraine (Péricart and Golub 1996, Aukema et al. 2013, Cho et al. 2020). 


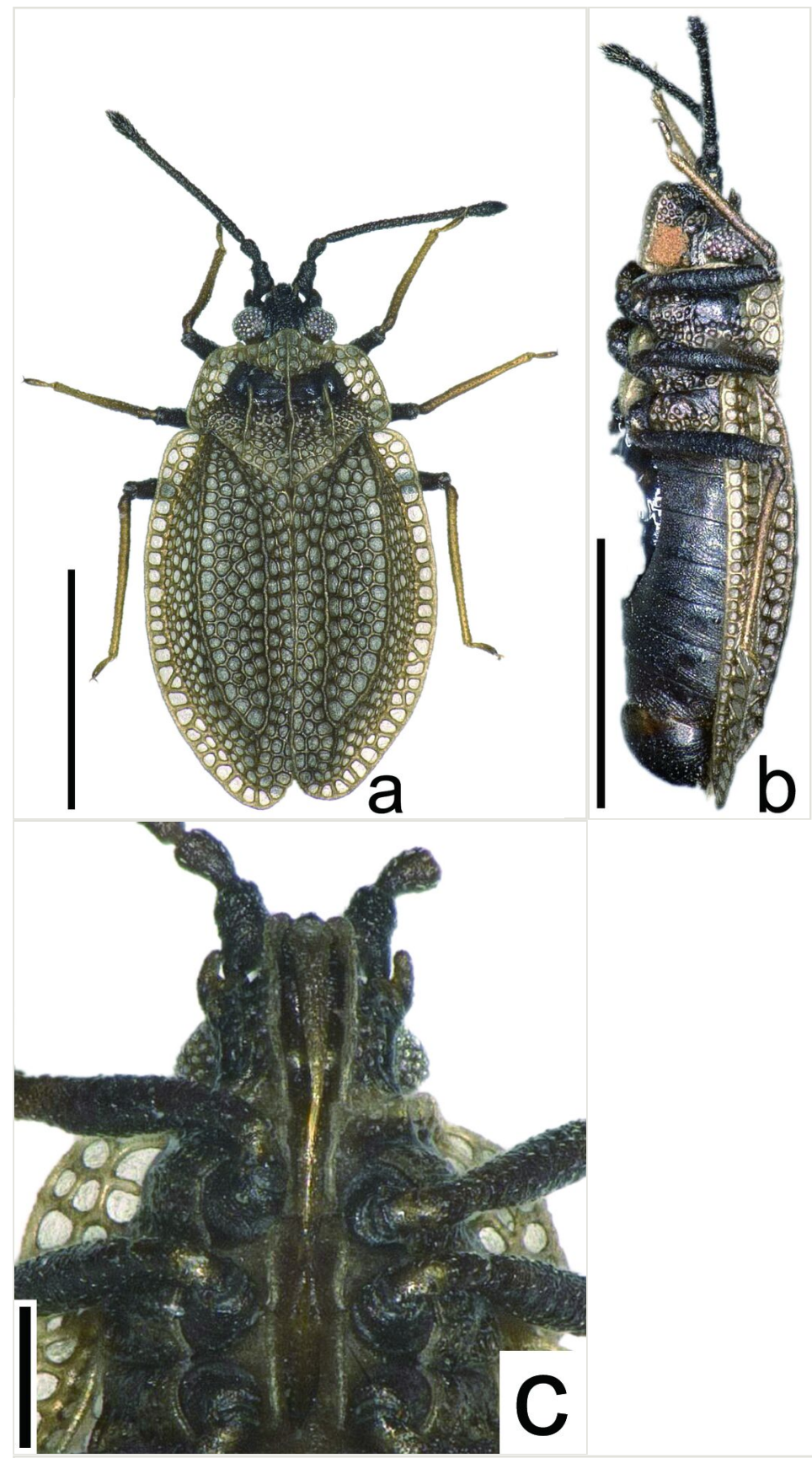

Figure 1.

Habitus images of Acalypta marginata from Hokkaido, Japan.

a: brachypterous male, dorsal view. Scale bar $1.0 \mathrm{~mm}$. doi

b: brachypterous male, lateral view. Scale bar $1.0 \mathrm{~mm}$. doi

c: rostrum, ventral view. Scale bar $0.2 \mathrm{~mm}$. doi 


\section{Biology}

The host plant for Acalypta marginata in Japan is unknown. In other distribution areas, A. marginata is found on Rhytidiadelphus sp. (Hylocomiaceae); it is also found on herbaceous plants (Putshkov 1974, Péricart 1983, Rédei et al. 2004, Rintala and Rinne 2011).

Acalypta marginata is found in grasslands in Japan. In other distribution areas, $A$. marginata is known to be found in dry and sunny environments, such as grassy ground; however, it is sometimes collected from humid and shaded environments, such as the forest floor (cf. Putshkov 1974, Rédei et al. 2004).

In Japan, adults have been collected only in July and the overwintering stage is unknown. In other distribution areas, adults are found in almost all seasons and the overwintering stage is known to be the adult or elder nymph (Putshkov 1974, Péricart 1983, Rédei et al. 2004, Rintala and Rinne 2011).

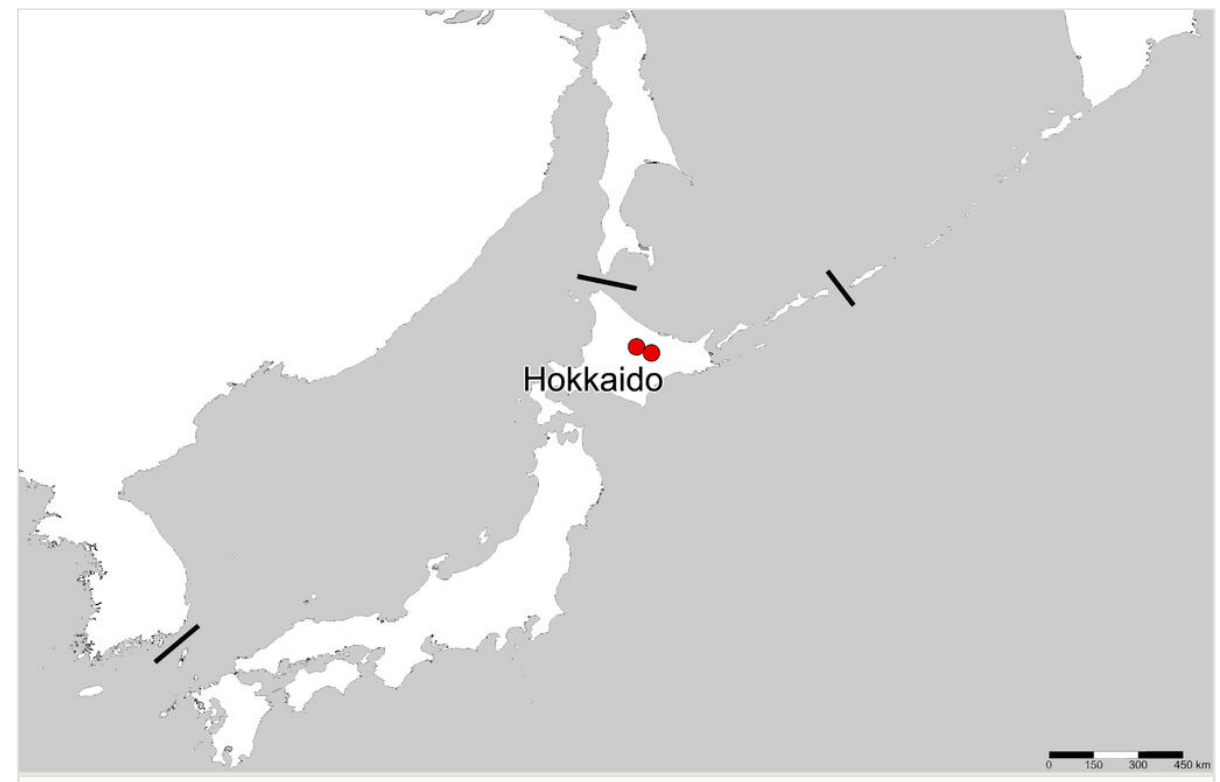

Figure 2. doi

Collection sites for Acalypta marginata from Hokkaido, Japan.

\section{Taxon discussion}

The above-recorded specimens match well with the photographs of the non-types (Rintala and Rinne 2011), descriptions (Wolff 1804, Péricart and Golub 1996) and keys (Putshkov 1974, Golub 1988) of Acalypta marginata described from Hungary, based on the brachypterous morph. 
Acalypta marginata is very similar to A. nigrina Fallén, 1807 in the shape of the antenniferous tubercles and the pronotum; however, the former is distinguished from the latter by the following characteristics: body fuscous and elongate in brachypterous morph (Fig. 1a, b). In contrast, A. nigrina has the following features: body dark grey and ovate in brachypterous morph.

\section{Identification keys}

\section{Key to the species of Acalypta occurring in Japan}

Both macropterous and brachypterous morphs known; pronotum

1 tricarinate; hypocostal lamina of hemelytron with a single row throughout

its length

Only brachypterous morph known; pronotum unicarinate; hypocostal

- lamina of hemelytron with 2 rows of areolae in basal part and a single row in remaining parts

Antenniferous tubercles pointed at apices, straight; anterolateral angle of

2 paranotum angular, strongly protruding anteriad, reaching mid-level of compound eye

A. cooleyi Drake, 1917

Antenniferous tubercles obtuse, slightly curved inwards; anterolateral angle of paranotum rounded, not protruding anteriad

3 Basal part of antennal segment III thickened

A. gracilis (Fieber, 1844)

- Basal part of antennal segment III not thickened

A. marginata

(Wolff, 1804)

Pronotum not less than 0.8 times as long as maximum width across

4 paranota; discoidal area considerably expanded beyond apical fourth of hemelytron, distinctly wider than subcostal area

Pronotum not more than 0.6 times as long as maximum width across

- paranota; discoidal area not expanded beyond apical fourth of hemelytron, 6 not wider than subcostal area

Posterolateral angle of paranotum protruding posteriad; posterior process 2.5 times as wide as its length; costal area with a single row of areolae throughout its length; subcostal area with 5 rows of areolae at widest part; Takeya, 1962 discoidal area with 5 rows of areolae at widest part 


\begin{tabular}{|c|c|c|}
\hline- & $\begin{array}{l}\text { Posterolateral angle of paranotum not protruding posteriad; posterior } \\
\text { process } 4 \text { times as wide as its length; costal area with } 2 \text { rows of areolae in } \\
\text { basal part and a single row in remaining parts; subcostal area with } 7 \text { rows } \\
\text { of areolae at widest part; discoidal area with } 6 \text { rows of areolae at widest } \\
\text { part }\end{array}$ & $\begin{array}{l}\text { A. pallidicoronata } \\
\text { Souma, } 2019\end{array}$ \\
\hline 6 & $\begin{array}{l}\text { Pronotum } 0.6 \text { times as long as maximum width across paranota; } \\
\text { anterolateral angle of paranotum weakly protruding anteriad, not reaching } \\
\text { mid-level of compound eye; posterolateral angle of paranotum protruding } \\
\text { posteriad; costal area with } 2 \text { rows of areolae in basal part }\end{array}$ & $\begin{array}{l}\text { A. sauteri Drake, } \\
1942\end{array}$ \\
\hline- & $\begin{array}{l}\text { Pronotum } 0.5 \text { times as long as maximum width across paranota; } \\
\text { anterolateral angle of paranotum strongly protruding anteriad, reaching } \\
\text { mid-level of compound eye; posterolateral angle of paranotum not } \\
\text { protruding posteriad; costal area with } 3-4 \text { rows of areolae in basal part }\end{array}$ & 7 \\
\hline 7 & $\begin{array}{l}\text { Paranotum with } 3 \text { rows of areolae throughout its length; costal area with } 3 \\
\text { rows of areolae in basal part, a single row in middle part and } 2 \text { rows in } \\
\text { apical part; and discoidal area as wide as subcostal area at widest part of } \\
\text { each }\end{array}$ & $\begin{array}{l}\text { A. miyamotoi } \\
\text { Takeya, } 1962\end{array}$ \\
\hline- & $\begin{array}{l}\text { Paranotum with } 4 \text { rows of areolae throughout its length; costal area with } 4 \\
\text { rows of areolae in basal part, } 2 \text { rows in middle part and } 3 \text { rows in apical } \\
\text { part; discoidal area narrower than subcostal area at widest part of each }\end{array}$ & $\begin{array}{l}\text { A. tsurugisana } \\
\text { Tomokuni, } 1972\end{array}$ \\
\hline
\end{tabular}

\section{Acknowledgements}

I express my sincere thanks to Dr. Viktor B. Golub (Voronezh State University, Voronezh, Russia), Dr. Barbara Lis (Opole University, Opole, Poland) and Dr. Eric Guilbert (Muséum national d'Histoire naturelle, France, Paris) for their critical comments on the manuscript. I am grateful to Prof. Tadashi Ishikawa (TUA) for the provision of the material for this study. This work was partially supported by a Grant-in-Aid for JSPS Fellows (JP20J20483) to authors from the Japan Society for the Promotion of Science, Tokyo, Japan. I would like to thank Editage (www.editage.jp) for English language editing.

\section{References}

- $\quad$ Aukema B, Rieger C, Rabitsch W (2013) Catalogue of the Heteroptera of the Palaearctic Region. Vol. 6, Supplement. The Netherlands Entomological Society, Amsterdam, 629 pp. [ISBN 978-90-71912-35-1]

- Cho G, Kim W, Kwon YS, Lee S (2020) Check list of lace bugs (Hemiptera: Tingidae) of Korea. Journal of Asia-Pacific Entomology 23 (3): 736-745. https://doi.org/10.1016/ j.aspen.2020.04.005 
- Drake CJ, Ruhoff FA (1965) Lacebugs of the world, a catalog (Hemiptera: Tingidae). Bulletin of the United States National Museum 243: 1-634. https://doi.org/10.5479/si. 03629236.243 .1

- Golub VB (1982) New data on the fauna of the lacebugs (Heteroptera, Tingidae) of the Mongolian People's Republic. Nasekomye Mongolii 8: 200-209. [In Russian, with English summary].

- $\quad$ Golub VB (1988) Fam. Tingidae. In: Lehr PA (Ed.) Key to the insects of the Far East of the USSR, Vol. 2: Homoptera and Heteroptera. Nauka Publishing House, Leningrad, 857-869 pp. [In Russian].

- Horváth G (1906) Synopsis tingitidarum regionis Palaearcticae. Annales HistoricoNaturales Musei Nationalis Hungarici 4: 1-117.

- Péricart J (1983) Hémiptères Tingidae euro-méditerranéens. Faune de France 69: 1-620. [In French].

- $\quad$ Péricart J, Golub VB (1996) Superfamily Tingoidea Laporte, 1832. In: Aukema B, Rieger C (Eds) Catalogue of the Heteroptera of the Palaearctic Region. Vol. 2, Cimicomorpha I. The Netherlands Entomological Society, Amsterdam, 3-78 pp. [ISBN 90-71912-15-9].

- Putshkov VG (1974) Beritidi, chervonoklopi, piezmatidi, pidkorniki i tingidi. Fauna Ukraini. Tom 21. Vipusk 4. Vidavnitstvo "Naukova Dumka”, Kiiv, 332 pp. [In Ukrainian].

- Rédei D, Harmat B, Hufnagel G (2004) Ecology of the Acalypta species occurring in Hungary (Insecta: Heteroptera: Tingidae). Data to the knowledge on the ground-living Heteroptera of Hungary, № 3. Applied Ecology and Environmental Research 2: 73-91. https://doi.org/10.15666/aeer/03073090

- Rintala T, Rinne V (2011) Suomen Luteet. 2. painos. Hyönteistarvike TIBIALE Oy, Helsinki, 352 pp. [In Swedish]. [ISBN 978-952-67-5440-6]

- Shorthouse DP (2010) SimpleMappr, an online tool to produce publication-quality point maps. http://www.simplemappr.net. Accessed on: 2020-12-23.

- Souma J (2019) A new species and a new record of the genus Acalypta (Hemiptera: Heteroptera: Tingidae) from Japan. Zootaxa 4609 (1): 178-184. https://doi.org/10.11646/ zootaxa.4609.1.10

- Souma J (2020) First record of the lace bug species Acalypta gracilis (Fieber, 1844) (Heteroptera: Tingidae) from Japan proper. Rostria 65: 66-70.

- Wolff JF (1804) Icones Cimicum descriptionibus illustratae. Fasc. 4. Apvd loannem lacobvm Palm, Erlangae, 40 pp.

- Yamada K, Ishikawa T (2016) Family Tingidae. In: Hayashi M, Tomokuni M, Yoshizawa K, Ishikawa T (Eds) Catalogue of the insects of Japan Volume 4 Paraneoptera. Toukashobo, Fukuoka, 429-435 pp. [In Japanese]. [ISBN 978-4-434-21822-4]. 